\title{
ICT IMPACT ON DEVELOPMENT OF KNOWLEDGE ECONOMY IN UKRAINE AND REPUBLIC OF MOLDOVA
}

\author{
Anastasia Stefanita ${ }^{1}$, Larysa Emelyanenko ${ }^{2}$ and Tetiana Shkoda ${ }^{3}$
}

\begin{abstract}
In this paper, the authors analysed the value of the development of information and communication technologies as an innovative resource of the knowledge economy. The analysis of the knowledge economy state of Ukraine and Republic of Moldovain the international dimension is conducted. The statistical analysis is based on macro data of the Global Innovation Index for the period 2012-2016 that limits the relevance of the results obtained. The practical examples of information and communication technologies used by public sector in the knowledge economy are described. It is proved the importance of information and communication technologies as a key component of the economic system based on knowledge.
\end{abstract}

The paper has the goal to underline the positive aspects of the knowledge economy in Ukraine and Republic of Moldova due to ICT tools but also to put into discussion the backlogs of the development processes in these countries.

\section{Introduction}

\subsection{The scope of the paper}

The knowledge economy is quite controversial phenomenon, as it puts innovation processes of different levels at the centre of the economic system. And the world competitiveness of any country is closely connected with the state of the development of the knowledge economy.

Transformation processes in Ukraine and Republic of Moldova connected with their European integration intentions require a deep reload of both their economic systems and public management. As both countries represent post-soviet states, it is interesting to compare the state of their knowledge economies development in general and the level of implementing information and communication technologies as an innovative resource of the knowledge economy at the example of public sector.

\subsection{General notes on knowledge economy}

Accelerated innovative transformation of the modern economy shows the increasing importance of knowledge as a decisive factor in innovation and technological development. Under the new conditions other basics of the globally competitive national economy, except in the form of a

\footnotetext{
1 Information Society Development Institute, 5A Academiei Str., Chisinau, MD-2028, Republic of Moldova, anastasia.stefanita@idsi.md

${ }^{2}$ Kyiv National Economic University named after Vadym Hetman, 54/1 Peremogy Prospect, Kyiv, 03680, Ukraine, larysa.yemelianenko@kneu.ua

${ }^{3}$ Kyiv National Economic University named after Vadym Hetman, 54/1 Peremogy Prospect, Kyiv, 03680, Ukraine, tetiana.shkoda@kneu.ua
} 
"knowledge economy" does not exist. This trend changes the configuration of the mechanism of economic growth [27].

The knowledge economy is defined as a special innovative model of production in the form of complementary information and communication technologies, human capital (using these technologies) and the creative potential of firms (implementing productivity of the first two elements) on the background of social networks, which will replace the traditional forms of organization of the market in the knowledge economy [2].

Deepening economic diversification, the predominance of a knowledge-based and high-tech products in the structure of GDP, the dominance of networking interaction of economic agents are the hallmarks of the knowledge economy's growth [7; 9].

Conceptual interpretation of the "knowledge economy" as a special production method understands it as a system, in which the processes of generation, application and dissemination of knowledge play a dominant role in the creation of tangible, material and intellectual wealth, as well as generally accepted social values.

In the public sector the knowledge economy has its own specifics. It requires the utilization of the knowledge in order to improve the transparence, the services delivering to the citizens, for a better communication with the citizens/users/clients and in order to improve the knowing degree of their needs [14].

\section{Knowledge economy state of Ukraine and Republic of Moldova}

Development of knowledge economy is defined by modern economic theory and practice of effective public and business activities as a key factor of the sustainable economic development. According to Mahfouz E. Tadros [20] knowledge-based development requires strong R\&D institutions, an industrial base, a pool of skills and competences, a strong physical and cyber infrastructure, and a business-friendly regulatory framework.

One of the strategic directions of development for Ukraine is modernization of its social and economic system on the base of implementing new technologies and innovations in all spheres of human activity, synchronization of the development of nature, economy and human [4]. Such modernization is also important for Moldova. Moreover, a big emphasis in Moldova is on IT development, that started from the government level (since 2011 through Governance eTransformation Program and Project with the World Bank support) and besides public processes is oriented as well to citizens and business.

Nowadays various frameworks and methodologies are used for assessing the development of knowledge economy of countries. These instruments are developed by such organizations as World Bank Institute [30], the Organization for Economic Cooperation and Development (OECD) [13], the European Union institutions [11], World Economic Forum [31] and the World Intellectual Property Organization in collaboration with Cornell University, INSEAD [25].

As the aim of our paper is to show the value of the development of information and communication technologies as an innovative resource of the knowledge economy, in our research we used the Global Innovation Index (GII) data for the period 2012-2016. It also helped us to present the analysis of the knowledge economy state of Ukraine and Republic of Moldova in the 
international dimension as GII is used as one of the main world indicators of the knowledge economy's state.

In general, according to the GII Report 2015 [24] the Innovation Input Sub-Index consists of five input pillars that capture the national economy elements that enable innovative activities and reflects the innovative character of the country's knowledge economy: (1) Institutions, (2) Human capital and research, (3) Infrastructure, (4) Market sophistication, and (5) Business sophistication. On the other hand, the Innovation Output Sub-Index is comprise of two output pillars that are the results of innovative activities within the economy: (6) Knowledge and technology outputs, (7) Creative outputs.

\subsection{Ukraine situation}

The analysis for Ukraine as a representative of the lower-middle-income countries in GII 2015 shows that from 2014 it remains in the top 10 countries of this group.

Ukraine outperformed its peers in at least four innovation input or output pillars of GII during 20112014 (Table 1). It is also positioned as an innovative achiever, but not improved its total GII ranking during 2014-2015. Ukraine demonstrates rising levels of innovation results because it has a skilled labor force with expanded tertiary education. In 2016 Ukraine takes $40^{\text {th }}$ position among the investigated countries in GII 2016 Report, but it has lost 4 positions in comparison with 2015 year. Despite this fact the result for (2) Human capital \& research in 2016 (40 $0^{\text {th }}$ place) is higher than in $2012\left(48^{\text {th }}\right.$ place $)$.

\begin{tabular}{|l|c|c|c|c|c|c|c|c|c|}
\hline Index & 2012 & $\begin{array}{c}\Delta 2013- \\
2012\end{array}$ & 2013 & $\begin{array}{c}\Delta 2014- \\
2013\end{array}$ & 2014 & $\begin{array}{c}\Delta 2015- \\
2014\end{array}$ & 2015 & $\begin{array}{c}\Delta 2016- \\
2015\end{array}$ & 2016 \\
\hline GII & 63 & $8 \downarrow$ & 71 & $8 \uparrow$ & 63 & $1 \downarrow$ & 64 & $8 \uparrow$ & 56 \\
\hline 1. Institutions & 117 & $12 \uparrow$ & 105 & $2 \uparrow$ & 103 & $5 \uparrow$ & 98 & $3 \downarrow$ & 101 \\
\hline $\begin{array}{l}\text { 2. Human } \\
\text { capital \& } \\
\text { research }\end{array}$ & 48 & $4 \uparrow$ & 44 & $1 \downarrow$ & 45 & $9 \uparrow$ & 36 & $4 \downarrow$ & 40 \\
\hline 3. Infrastructure & 98 & $7 \uparrow$ & 91 & $16 \downarrow$ & 107 & $5 \downarrow$ & 112 & $13 \uparrow$ & 99 \\
\hline $\begin{array}{l}\text { 4. Market } \\
\text { sophistication }\end{array}$ & 68 & $14 \downarrow$ & 82 & $8 \downarrow$ & 90 & $1 \uparrow$ & 89 & $14 \uparrow$ & 75 \\
\hline $\begin{array}{l}\text { 5. Business } \\
\text { sophistication }\end{array}$ & 51 & $28 \downarrow$ & 79 & $8 \downarrow$ & 87 & $9 \uparrow$ & 78 & $5 \uparrow$ & 73 \\
\hline $\begin{array}{l}\text { 6. Knowledge \& } \\
\text { technology } \\
\text { outputs }\end{array}$ & 30 & $15 \downarrow$ & 45 & $13 \uparrow$ & 32 & $2 \downarrow$ & 34 & $1 \uparrow$ & 33 \\
\hline $\begin{array}{l}\text { 7. Creative } \\
\text { outputs }\end{array}$ & 83 & $2 \uparrow$ & 81 & $4 \uparrow$ & 77 & $2 \uparrow$ & 75 & $17 \uparrow$ & 58 \\
\hline
\end{tabular}

Table 1: GII for Ukraine

Source: composed and calculated by the authors on the basis of $[21 ; 22 ; 23 ; 24 ; 25]$

The country demonstrates the lowest results by such indicators as Institutions and Infrastructure among other innovative inputs. Despite this fact, there is a conventionally positive dynamics for $2012-2016$ by theses indicators. For example, $117^{\text {th }}$ place $(2012), 103^{\text {rd }}$ place $(2014)$ and $101^{\text {st }}$ place 
(2016) of Ukraine by (1) Institutions show that the country isn't attractive very much for businesses and doesn't provide good governance and the correct levels of protection and incentives that are essential to innovation.

At the same time there is some negative dynamics for (4) Market sophistication and (5) Business sophistication, especially in 2012-2014. There is a statement in the concept of reform of government policy in the field of innovations approved by Resolution of the Cabinet of Ministers of Ukraine (CMU) no. 691 of 10.09.2012 that the majority of businesses are technologically backward and energy-intensive. It is connected with bad market conditions and a lack of credit investments for innovations development. And it also demonstrates the failure of the state innovation policy of Ukraine and its principle of independent innovation development.

It is visible that there is a gap between such pillar as (2) Human capital \& research and all other elements of GII for Ukraine.

By innovative outputs Ukraine takes good position in GII ranking. In 2016 it has $33^{\text {rd }}$ place by (6) Knowledge \& technology outputs and $58^{\text {th }}$ place by (7) Creative outputs. Comparing the country's positions for the 2012-2016 periods by these indicators, the authors should admit that Ukraine has saved the average results for (6) Knowledge \& technology, but it has also improved its results by (7) Creative outputs for the same period of time ( $83^{\text {rd }}$ place in 2012 and $58^{\text {th }}$ place in 2016).

To improve its innovativeness and competitiveness on the way of transformation to the knowledge economy in 2013 CMU adopted the Strategy of information society development in Ukraine by Resolution no. 386-p of 15.05.2013. To realise this strategy in 2015 Ukraine joined Horizon 2020 to work with EU in science and research. The agreement was ratified by the Ukrainian Parliament and entered into force. According to it Ukrainian legal entities can participate in all Horizon 2020 actions funded under the 2015 budget, as this association covers the years 2015-2020 [5].

\subsection{Republic of Moldova situation}

According to the Global Innovation Index Report from 2015, the Republic of Moldova is one of the eleven developing countries that are labelled 'innovation outperformers' because they conform to the following two more stringent rules:

- $\quad$ their GII score relative to their GDP is significantly higher than it is for other economies (they attain 'innovation achiever' status) for two or more recent years (including at least 2013 and 2014);

- $\quad$ they outperform their income-group peers in a minimum of four innovation input or output pillars (they are designated 'pillar outperformers') for two or more years (including at least 2013 and 2014).

On average, the technology gap between developing and developed countries appears to be narrowing. One explanation is that more and more developing countries outperform in innovation inputs and outputs relative to their level of development (Moldova's case). Among other developing countries, Moldova have realized that technology adoption alone is no longer sufficient to maintain a high-growth scenario; rather innovation is now crucial for catching up to high-income countries. As a result, national innovation policy programmes are flourishing in low- and middle-income countries. The Republic of Moldova has been identified as one of the rising innovators in Europe. 
Its performance has been consistent in almost all innovation inputs and outputs during 2011-14 (Table 2). It performed above $75 \%$ of the economies in the GII in Knowledge and technology outputs and Creative outputs. These high scores are the result of high numbers of utility model applications and trademark registrations. Indeed, government efforts towards increasing intellectual property rights awareness and encouraging its use led to the establishment of the State Agency on Intellectual Property and the implementation of a National Intellectual Property Strategy, which have been in place since 2011 and 2012, respectively. These efforts may at least partially explain the country's high scores in these indicators. The Republic of Moldova performs poorly in Business sophistication, however, because of weak innovation linkages — in particular its limited cluster development and university-industry collaborations [24].

\begin{tabular}{|l|c|c|c|c|c|c|c|c|c|}
\hline \multicolumn{1}{|c|}{ Index } & $\mathbf{2 0 1 2}$ & $\begin{array}{c}\Delta \mathbf{2 0 1 3}- \\
\mathbf{2 0 1 2}\end{array}$ & $\mathbf{2 0 1 3}$ & $\begin{array}{c}\Delta \mathbf{2 0 1 4} \\
\mathbf{2 0 1 3}\end{array}$ & $\mathbf{2 0 1 4}$ & $\begin{array}{c}\Delta \mathbf{2 0 1 5} \\
\mathbf{2 0 1 4}\end{array}$ & $\mathbf{2 0 1 5}$ & $\begin{array}{c}\Delta \mathbf{2 0 1 6} \\
\mathbf{2 0 1 5}\end{array}$ & $\mathbf{2 0 1 6}$ \\
\hline GII & 50 & $5 \uparrow$ & 45 & $2 \uparrow$ & 43 & $1 \downarrow$ & 44 & $\mathbf{2} \downarrow$ & 46 \\
\hline 1. Institutions & 78 & $6 \downarrow$ & 84 & $4 \uparrow$ & 80 & $5 \uparrow$ & 75 & $\mathbf{7 \uparrow}$ & 68 \\
\hline $\begin{array}{l}\text { 2. Human } \\
\text { capital \& } \\
\text { research }\end{array}$ & 55 & $6 \uparrow$ & 49 & $22 \downarrow$ & 71 & $3 \downarrow$ & 74 & $\mathbf{2 3 \uparrow}$ & 51 \\
\hline 3. Infrastructure & 85 & $4 \uparrow$ & 81 & $7 \downarrow$ & 88 & $6 \uparrow$ & 82 & $\mathbf{7 \uparrow}$ & 75 \\
\hline $\begin{array}{l}\text { 4. Market } \\
\text { sophistication }\end{array}$ & 96 & $17 \uparrow$ & 79 & $30 \uparrow$ & 49 & $3 \downarrow$ & 52 & $\mathbf{4 1} \downarrow$ & 93 \\
\hline $\begin{array}{l}\text { 5. Business } \\
\text { sophistication }\end{array}$ & 104 & $19 \uparrow$ & 85 & $17 \downarrow$ & 102 & $19 \uparrow$ & 83 & $\mathbf{6} \downarrow$ & 89 \\
\hline $\begin{array}{l}\text { 6. Knowledge \& } \\
\text { technology } \\
\text { outputs }\end{array}$ & 31 & $5 \uparrow$ & 26 & $0 \leftrightarrow$ & 26 & $0 \leftrightarrow$ & 26 & $\mathbf{5} \downarrow$ & 31 \\
\hline $\begin{array}{l}\text { 7. Creative } \\
\text { outputs }\end{array}$ & 32 & $0 \leftrightarrow$ & 32 & $0 \leftrightarrow$ & 32 & $6 \downarrow$ & 38 & $\mathbf{4} \uparrow$ & 34 \\
\hline
\end{tabular}

Table 2: GII for Moldova

Source: composed and calculated by the authors on the basis of $[21 ; 22 ; 23 ; 24 ; 25]$

The Republic of Moldova introduced its innovation strategy 'Innovations for Competitiveness' for the period 2013-2020. This strategy aims to stimulate innovation in firms and society in general. In the same context, the Strategy for Research and Development of the Republic of Moldova until 2020 was drafted under the guidance of the Academy of Sciences of Moldova and approved by the Government in December 2013, aiming at increasing investments in research and development to $1 \%$ of GDP by 2020 . None of the strategies clearly identifies thematic priorities (for example, in the Research and Development Strategy the six societal challenges of Horizon 2020 are mentioned as priorities). During last months of 2016 several decisions were taken referring to Government reform through restructuring the ministries and other central institutions, including research and development \& innovation sector. In this respect would follow several mergers, transfer of responsibilities and other institutional and functional changes.

The number of persons employed in Research \& Development sector in Moldova decreased significantly due to "brain drain", while among the remaining researchers a certain ageing trend can be observed. At the same time, the R\&D field is unattractive (from salary and existing infrastructure points of view) for young talents. The level of knowledge obtained in local universities does not meet market expectations, while attraction of foreign students or researchers is difficult due to unappealing conditions [1]. 
Both Ukraine and Republic of Moldova belong to the 14 middle-income countries outperforming others in their income group [24]. But, in general, Republic of Moldova takes stronger positions in different components of GII than Ukraine. It happens because of more successful government policy in different spheres of knowledge economy.

\section{ICT tools used by public sector in the knowledge economy}

Information and communication technologies (ICT) provide almost unlimited possibilities of doing business, scientific and research, artistic and other activities in the Internet, and they allow citizens to participate in forming the policy of developing society, economy and education. ICT, which provided the basis for the knowledge economy, continue to develop and offer the possibility of using new approaches to social and economic development [29]. For example, it is done by involving citizens into the innovation activity. The greatest attention should be paid to communication channels and means of communication and exchange of information between citizens (consumers), manufacturers and governments to use the intellectual potential of society [16].

Currently, a set of ICT goes into a new quality of the interaction with public authorities and private companies. Modern citizens have an opportunity to participate in the discussion of public decisions and influence the formation of national and municipal policies by e-government tools. The use of ICT in the economy allows companies to reach new economic effects by adapting to the everchanging business environment, the creation of mobile offices, continuous communication with partners and customers.

A new type of communication between citizens, producers and governments via ensuring the free exchange of information is one of the main advantages of the knowledge economy [18].

Key changes occur in the field of mass interaction of public authorities with citizens in the following areas: development of electronic interagency cooperation; providing services in electronic form; development of portals and provision of information on the activities of public authorities; implementation of a universal electronic citizen card. They form the primary basis, the foundation of the "electronic government"; provide a transition of traditional bureaucratic functions in the Internet space. In each of these areas, the government makes great efforts: creates and adapts the regulatory framework, develops and distributes software solutions, conducts constant coordination with the regions and municipalities, sets the pace of development, overcomes resistance, allocates huge resources, etc.

The dynamics of ICT development in public sector of the analysed countries is presented in Table 3 and Table 4. These tables consist of the indicators that are the part of (3) Infrastructure pillar of the Innovation Input Sub-Index of the GII. The basic results are gathered and calculated by the World Intellectual Property Organization in collaboration with Cornell University, INSEAD [21; 22; 23; 24; 25]. The authors composed the data of the tables based on Ukraine and Moldova countries' profiles and then calculated the changes by years. 


\begin{tabular}{|l|c|c|c|c|c|c|c|c|c|}
\hline \multicolumn{1}{|c|}{ Index } & $\mathbf{2 0 1 2}$ & $\begin{array}{c}\Delta \mathbf{2 0 1 3 -} \\
\mathbf{2 0 1 2}\end{array}$ & $\mathbf{2 0 1 3}$ & $\begin{array}{c}\Delta \mathbf{2 0 1 4 -} \\
\mathbf{2 0 1 3}\end{array}$ & $\mathbf{2 0 1 4}$ & $\begin{array}{c}\Delta \mathbf{2 0 1 5} \\
\mathbf{2 0 1 4}\end{array}$ & $\mathbf{2 0 1 5}$ & $\begin{array}{c}\Delta \text { 2016- } \\
\mathbf{2 0 1 5}\end{array}$ & $\mathbf{2 0 1 6}$ \\
\hline ICTs & 77 & $2 \downarrow$ & 79 & $5 \downarrow$ & 84 & $5 \downarrow$ & 89 & $2 \uparrow$ & 87 \\
\hline ICT access & 58 & $8 \downarrow$ & 66 & $2 \uparrow$ & 64 & $1 \uparrow$ & 63 & $1 \uparrow$ & 62 \\
\hline ICT use & 81 & $15 \uparrow$ & 66 & $21 \downarrow$ & 87 & $2 \downarrow$ & 89 & $3 \downarrow$ & 92 \\
\hline $\begin{array}{l}\text { Government's } \\
\text { online service }\end{array}$ & 88 & $1 \downarrow$ & 89 & $1 \downarrow$ & 90 & $22 \downarrow$ & 112 & $7 \uparrow$ & 105 \\
\hline E-participation & 78 & $1 \downarrow$ & 79 & $0 \leftrightarrow$ & 79 & $3 \uparrow$ & 76 & $2 \uparrow$ & 74 \\
\hline
\end{tabular}

Table 3: ICTs for Ukraine

Source: composed and calculated by the authors on the basis of $[21 ; 22 ; 23 ; 24 ; 25]$

Ukraine is not among the leaders in the world by ICT (Table 3). In 2016 the country takes only $87^{\text {th }}$ place. It could be explained by the fact that several important legislative reforms such as the Law on Citizens' Petitions (2015), Law on Access to Public Information and Open Data (2015) and the Law on the Open Use of Public Funds were passed in Ukraine.

Government's online service, especially the e-declaration system as its key part, is the most discussed topic in Ukraine during 2016. Now everyone has access to the information about assets and revenues of officials as foreseen by the law № 1022-VIII adopted by the Verkhovna Rada on 15 of March this year [10].

The development of e-governance in Ukraine is also one of the main goals of the EU and Council of Europe joint programme „Strengthening Information Society in Ukraine“ [3]. This program aims at improving the freedom, diversity and pluralism of the media and strengthening personal data protection.

E-governance in Ukraine is only in its infancy. The country has all the necessary technical equipment to establish a functional system of electronic governance. The main challenge is the insufficient digital literacy of citizens and civil servants [6].

A recent national OMNIBUS public opinion survey showed ordinary Ukrainian citizens are not very aware of the possible benefits of e-government and e-democracy initiatives: $86 \%$ did not understand what e-government means, $79 \%$ have never heard of the term e-democracy and only $41 \%$ thought that they may have some idea of the term's meaning [26].

Ukraine should use its IT as a socio-economic driver for the knowledge economy transformation. Ukraine's 402 universities and colleges annually produce more science graduates than many reputable hi-tech countries in Asia and Western Europe. Ukraine's 90,000 IT professionals is the largest professional IT community in Europe with the numbers expected to rise to over 200,000 in 2020 [26]. So, Ukrainian government just should use this resource in the appropriate way.

Republic of Moldova has better situation with ICT development than Ukraine. The current ICT market in Moldova is primarily in a buildout phase, with major investments focused on basic hardware infrastructure, such as server, storage, infrastructure software, and network equipment implementations. In 2016 Moldova takes $51^{\text {st }}$ position by the ICT indicator in GII Report (Table 4).

Moldova has one of the best-wired Internet connections in the world as well as one of the cheapest in terms of price per Mbit. The overall infrastructure is well developed which allows many users to 
experience good quality services throughout the country. However, despite high speeds and cheap prices, the penetration level is quite low when compared with many EU or CIS countries [12].

\begin{tabular}{|l|c|c|c|c|c|c|c|c|c|}
\hline \multicolumn{1}{|c|}{ Index } & $\mathbf{2 0 1 2}$ & $\begin{array}{c}\Delta \mathbf{2 0 1 3 -} \\
\mathbf{2 0 1 2}\end{array}$ & $\mathbf{2 0 1 3}$ & $\begin{array}{c}\Delta \mathbf{2 0 1 4 -} \\
\mathbf{2 0 1 3}\end{array}$ & $\mathbf{2 0 1 4}$ & $\begin{array}{c}\Delta \mathbf{2 0 1 5} \\
\mathbf{2 0 1 4}\end{array}$ & $\mathbf{2 0 1 5}$ & $\begin{array}{c}\Delta \mathbf{2 0 1 6 -} \\
\mathbf{2 0 1 5}\end{array}$ & $\mathbf{2 0 1 6}$ \\
\hline ICTs & 56 & $6 \uparrow$ & 50 & $8 \downarrow$ & 58 & $10 \uparrow$ & 48 & $3 \downarrow$ & 51 \\
\hline ICT access & 55 & $1 \uparrow$ & 54 & $1 \downarrow$ & 55 & $0 \leftrightarrow$ & 55 & $2 \uparrow$ & 53 \\
\hline ICT use & 57 & $2 \uparrow$ & 55 & $19 \downarrow$ & 74 & $17 \uparrow$ & 57 & $4 \downarrow$ & 61 \\
\hline $\begin{array}{l}\text { Government's } \\
\text { online service }\end{array}$ & 61 & $0 \leftrightarrow$ & 61 & $1 \downarrow$ & 62 & $3 \downarrow$ & 65 & $5 \uparrow$ & 60 \\
\hline E-participation & 38 & $0 \leftrightarrow$ & 38 & $0 \leftrightarrow$ & 38 & $2 \uparrow$ & 40 & $0 \leftrightarrow$ & 40 \\
\hline
\end{tabular}

Table 4: ICTs for Moldova

Source: composed and calculated by the authors on the basis of $[21 ; 22 ; 23 ; 24 ; 25]$

The Republic of Moldova achieved significant progress in the implementation of information society technologies, ICT contribution share to GDP in recent years has reached the level of almost $8-10 \%$, every second citizen is an Internet user, more than half of households have at least one computer, the majority of connected households have access to broadband Internet, the biometric passport, the ID card with electronic signature, the e-Statements system and digital map were implemented, country joined the "Open Government Data" initiative, etc. However, in international classifications the country is not placed among the advanced economies in this field, and the level and speed of information society development do not meet the current international environment requirements, in which the world is becoming even more "hyperconnected" and more digitized [8].

The regulatory framework in ICT field is more or less functional and partial harmonised with European norms. The Government of the Republic of Moldova has recognized the need to use ICT as a crosscutting enabler of sustainable growth, competitiveness and improved governance, and in this context, it has requested the World Bank's assistance to enable the e-transformation of Moldova. The Governance e-Transformation Project is designed to increase efficiency and quality of a selected range of public services to citizens and businesses and improve management of ICT in the public sector [17]. E-Transformation Strategy (from 2011) is a logical continuation of actions undertaken beginning with 1990 (when was started the institutional framework) and 1993 (start of the legal and methodological framework development) and later 2005 when was implemented the National Strategy for Information Society Action Plan „Electronic Moldova”.

Among other initiatives, within e-Transformation project a unique platform (servicii.gov.md) for public services provided by the authorities was launched in 2012. The servicii.gov.md platform functions as an electronic catalogue for public services provided by the authorities dedicated to citizens and the business environment. The main purpose of this platform is to offer brief, correct, accessible and complete information on the public services available in the Republic of Moldova. On the platform, can be found information regarding both electronic services, as well as traditional services. Currently, there are 566 services on the portal, of which 125 are e-Services (on-line services) with data opened for access [15]. The Republic of Moldova Government is determined to transform all traditional counter services into e-services by 2020, through the „Open Government action plan" and the „Government technological modernisation strategy”. In this way, the citizens will be able to access over 500 e-services. 
Referring to e-participation the Moldavian government launched in 2012 the "particip.gov.md" platform. Through this platform citizens can be consulted on various draft laws. Until now almost 2500 drafts of Government Decisions, 775 Law drafts, 170 strategies, 115 Regulations and 300 other draft policies were published for large consultation on the platform.

Talking about IT tools in public sector, it should be mentioned the pilot-project Management System of Documents and Authorities Registrations (SIGEDIA) that is part of the Action Plan for the initiative implementation "Paperless Government" in Moldova, approved through Government Decision no. 262 from 15.04.2013. Through SIGEDIA, the electronic circulation of the documents inside the Government is much more reliable, the system replacing the huge amount of paper that was being used in the executive with electronic documents. The electronic documents used by the ministries have the same juridical power as the ones on paper. Another provision of this project requires clerks to use professional email addresses (gov), so that the use of multiple public communication platforms would be eliminated. The system "sigedia.gov.md" was implemented in the State Chancellery and 7 ministries [19].

The rise in demand for exports in manufacturing, the growing usage of IT in the finance sector, transformations in the telecommunications industry, and demand in the government sector will fuel IT services market growth. Since the public sector (government administration, defence, police, judiciary, healthcare, education, and state-owned public enterprises) accounts for the bulk of IT spending in Moldova, it is crucial for IT vendors to be proactive in their dealings with this vertical market. This means educating policymakers and civil servants in decision-making positions in particular, conducting marketing studies and benchmarking, and organizing conferences, as well as offering attractive financial arrangements, outsourcing, and more. Current and future investments in Government IT will represent the main driving force in the Moldovan IT Services market in the near future [28].

\section{Conclusions}

In the long term, the IT services market of Moldova is expected to be driven primarily by large government projects, such as new e-government initiatives and technology investments in highly competitive sectors (e.g., banking and telecommunications) and initiatives that support the alignment of IT with business goals. The Moldovan government is expected to continue to upgrade public infrastructure, and remain committed to e-government initiatives aimed at improving the quality of public services [28] countrywide.

Ukraine has less developed ICT sphere than Republic of Moldova. Ukraine has the potential to do much more in modernizing its public administration system and in utilizing domestic human capital in the ICT sphere. Ukrainian government should change its attitude to the country's human capital as a resource to export, but has to consider the ICT sphere's human capital also as a key resource to strengthen the public sector of the state.

\section{References}

[1] Academy of Sciences of Moldova. The Knowledge Triangle in Moldova. Chisinau, 2016. Available at: http://www.ase.md/files/proiecte/fktbum.pdf accessed on 14.12.2016

[2] BAZHAL IU, M.: Knowledge economy: theory and public policy (Znannieva ekonomika: teoria i derzhavna polityka). Ekonomika i prognozuvannia $2003 \mathrm{Nr} 3$, pp. 71-86. 
[3] Council of Europe Office in Ukraine. Strengthening Information Society in Ukraine. Available at: http://www.coe. int/en/web/kyiv/41 accessed on 27.12.2016.

[4] Emelyanenko L. M.. Synergetic approach in the methodology of managing the economic development of Ukraine (Synergetychnyj pidkhid v metodologii upravlinnia ekonomichnym rozvytkom Ukrainy). Visnyk Lvivskogo universytetu. Seria ekonomichna. Issue 51, 2014, pp. $32-40$.

[5] European Commission: Ukraine joins Horizon 2020 to work with EU in science and research, 2015. Available at: http://europa.eu/rapid/press-release_IP-15-4640_en.htm accessed on 27.12.2016.

[6] EU in Ukraine: E-governance in Ukraine: challenges and opportunities, Cooperation News, 2015. Available at: https://euukrainecoop.com/2015/06/02/e-gov/ accessed on 28.12.2016.

[7] FEDULOVA, L. I. and Kotneeva, T. M.: Features of the knowledge economy in the modern phase of development of society. Theory and practice of building in Ukraine. (Osoblyvosti ekonomiky znan na suchasnij fazi rozvytku suspilstva. Teoria i praktyka rozbudovy v Ukraini.). Aktualni problem ekonomiky i praktyky. Nr 4, Vol. 106, 2010, pp. 74-86.

[8] Government of the Republic of Moldova: National Strategy for the development of information society „Digital Moldova 2020”, Decision no. 857 from 31.10.2013. Available at: http://www.mtic.gov.md/sites/default/files/transparency/public_consults/hg_857_31_10_2013 _nationalstrategymoldovadigitala2020en.pdf accessed on 14.12.2016.

[9] HEYETS, V. M.: Character of transition processes to knowledge economy (Kharakter perehidnykh protsesiv do ekonomiky znan). Ekonomika Ukrainy, $2004 \mathrm{Nr} 4$, pp. 4-14; Nr 5, pp. 4-13.

[10] HIEMSTRA, J.: E-declaration is a real breakthrough in Ukrainian reforms, 2016. Available at: http://www.ua.undp.org/content/ukraine/en/home/ourperspective/ourperspectivearticles/ 2016/10/31/e-declaration-is-a-real-breakthrough-in-ukrainian-reforms.html accessed on 28.12.2016.

[11] Innovation Union Scoreboard (IUS): The Innovation Union's performance scoreboard for Research and Innovation, 2010. Available at: https://ec.europa.eu/research/innovationunion/pdf/iu-scoreboard-2010_en.pdf accessed on 10.12.2016.

[12] Internet in Moldova. Wikipedia. Available at: https://en.wikipedia.org/wiki/Internet_in_ Moldova accessed on 14.12.2016.

[13] Organization for Economic Cooperation and Development (OECD): OECD Science, Technology and Industry Scoreboard, 2005. Available at: http:/www.oecdlibrary.org/docserver/download/9205071e.pdf?expires=1481630258\&id=id\&accname=guest \&checksum=57B44E4958023D428F1BC2E0215BD7C4 accessed on 10.12.2016

[14] PĂCEŞILĂ, M: The impact of moving to knowledge based economy in the public sector, 2006. Available at: http://www.mnmk.ro/documents/2006/2006-14.pdf accessed on 28.12.2016. 
[15] Public services platform of Moldova. Available at: https://servicii.gov.md/ accessed on 14.12.2016.

[16] RABOTA YU, I.: Public Relations as Public Administration Institute (Zv'jazky z gromadskistiu jak instytut derzhavnogo upravlinnia) : $\mathrm{PhD}$ Thesis on public management. Kharkiv, 2006, p. 20.

[17] Report on e-Transformation project 2015, Moldova. Available at: http://www.egov.md/en/ transparency/reports/governance-e-transformation-project-moldova-report-period-2013-2015 accessed on 20.12.2016.

[18] SIBIRIAKOV, S.: Communication practices in public management in context of the information society development (Komunikatyvni praktyky u derzhavnomu upravlinni v konteksti rozvytku informatsijnogo suspilstva), Derzhavne upravlinnia, 2010. Available at: http://www.nbuv.gov.ua/portal/soc_gum/Pubupr/2010/2010-34/doc/1/16.pdf

[19] SIGEDIA - electronic document management system for Central Public Administration of Moldova.. Available at: http://www.egov.md/en/projects/sigedia accessed on 20.12.2016.

[20] TADROS, M.E.: The Arab Gulf States and the Knowledge Economy: Challenges and Opportunities, 2015. Available at: http://www.agsiw.org/wp-content/uploads/2015/07/ Tadros_Knowledge-Economy_Rev1.pdf accessed on 24.12.2016.

[21] The Global Innovation Index 2012, Stronger Innovation Linkages for Global Growth. Available at: https://www. global innovationindex. org/userfiles/file/gii-2012-report.pdf accessed on 12.12.2016.

[22] The Global Innovation Index 2013. The Local Dynamics of Innovation. Available at: http://www.wipo.int/edocs/ pubdocs/en/economics/gii/gii_2013.pdf accessed on 12.12.2016.

[23] The Global Innovation Index 2014. The Human Factor in Innovation. Available at: http://global-indices.insead. edu/gii/documents/GII2014report.pdf accessed on 12.12.2016.

[24] The Global Innovation Index 2015. Effective Innovation Policies for Development. Available at: https://www. globalinnovationindex.org/userfiles/file/reportpdf/GII-2015-v5.pdf accessed on 12.12.2016.

[25] The Global Innovation Index 2016. Winning with Global Innovation. Available at: https://www.global innovationindex.org/gii-2016-report accessed on 12.12.2016.

[26] TOMKOVA, J.: How Is Ukraine Advancing In E-Government And E-Democracy? 2016. Available at: http://odessare view.com/ukraine-advancing-e-government-e-democracy/ accessed on 28.12.2016.

[27] UNESCO: Towards Knowledge Societies, 2005. Available at: http://unesdoc.unesco.org/ images/0014/001418/ 141843e.pdf accessed on 11.12.2016.

[28] USAID CEED II Moldova and GIZ GmbH. 2014. Competitiveness Assessment of Moldovan IT Services Industry. November 2014. Available at: http://www.mtic.gov.md/sites/default 
/files/staticdocuments/competitiveness-assessment-of-moldovan-it-services-industry.pdf accessed on 14.12.2016.

[29] Webster F. Theories of the information society. $3^{\text {rd }}$ ed. Taylor $\&$ Francis Group. Routledge. 2006,323 p.

[30] World Bank Institute (WBI) 2007. Building Knowledge Economies. Advanced Strategies for Development. Available at: http://siteresources.worldbank.org/KFDLP/Resources/4611971199907090464/BuildingKEbook.pdf accessed on 11.12.2016.

[31] World Economic Forum: The Global Information Technology Report. (WEF GITR) 2015. Available at: http://www3.weforum.org/docs/WEF_Global_IT_Report_2015.pdf accessed on 11.12.2016. 